\title{
1881 TARİHLİ ŞEHBENDERLER NIZAMNAMESİ ÜZERİNE BİR İNCELEME
}

\section{THE CONSULS REGULATIONS DATED 1881 ON A REVIEW}

\section{Emre GÖR*}

\section{$\ddot{O} \mathbf{z}$}

Osmanlı İmparatorluğu XIX. yüzyılın son çeyreğine girilirken iç ve dış birçok problemle uğraşmak zorunda kalmıştı. Bir yandan imparatorluğu ayakta tutmak ve güçlendirmek için Tanzimat'tan kalan sslahat girişimlerinin devam etme zorunluluğu varken, diğer taraftan XIX. yüzyıl başlarında ilk emareleri görülen ayaklanma hareketleri yeniden filizlenmişti. Böyle bir ortamda yönetimi devralan II. Abdülhamid, her ne kadar iktidarının ilk yıllarında kontrolü dışında gelişen dış meseleler yüzünden iç işlerine esaslı olarak eğilemese de, takriben 1880 yılından sonra iç işlerinde bir dizi düzenlemeye gitme firsatı yakalamıştı. Bu kapsamda birçok alanda nizamnameler neşredilmiş, bu nizamnamelerle devlet işlerinin belirli bir düzen çerçevesinde yürütülmesi sağlanmaya çalışılmıştır. Bu çalı̧̧mada, II. Abdülhamid döneminde Osmanlı İmparatorluğu adına yurtdışında görevli şehbenderlere dair yayımlanan ilk nizamname olan ve şehbenderlik teşkilatına dair önemli bir metin özelliği taşıyan 1881 tarihli Şehbenderler Nizamnamesi incelenerek, şehbenderlik müessesinin anlaşılmasına katkı sağlamak amaçlanmıştır.

Anahtar Kelimeler: Şehbender, Şehbenderhane, Nizamname, Hariciye Nezareti, II. Abdülhamid.

Jel Kodlar: Z10, Z19

\begin{abstract}
While the Ottoman Empire was entering the last quarter of the 19th century, it had to deal with many internal and external problems. On the one hand, in order to sustain and strengthen the empire, the reforms attempts from the Tanzimat must continue; while on the other hand, the uprising movements, whose first signs was seen in the early 19th century, was re-sprouted. Abdulhamid II, who took over the administration in such an environment, had not been able to focus on his internal affairs because of the external issues that emerged in the first years of his rule; but after about 1880, he had the opportunity to undertake a series of internal affairs. Within this scope, regulations were made in many areas and it was tried to ensure that the state affairs were carried out within the framework of a certain order. In this study, it was aimed to contribute to the understanding of the consulate organization by examining the Consuls Regulations of 1881, which was the first regulations published in the period of Abdulhamid II in the Ottoman Empire, and which was an important text about the organization of the Consortium.
\end{abstract}

Key Words: Consul, Consulate, Regulations, Foreign Ministry, Abdulhamid II.

Jel Codes: Z10, Z19

Giriş

${ }^{*}$ Dr. , Araştırmac1. emregor1987@ gmail.com, 0000-0001-8208-6714 
Osmanlı İmparatorluğu'nun oldukça zor bir dönemde olduğu 1876 y1lında yönetimi devralan II. Abdülhamid, devletlerarası sahada büyük zorluklarla karşı karşıya kalmış olan bir imparatorluğun başına geçmişti. Batılıların Balkanlarda filizlenen isyan ateşine istinaden "Büyük Doğu Buhranı" olarak adlandırdıkları 1875-1878 aralığına denk gelen bu dönem, bilhassa Balkanlarda devam eden ayaklanma ve fiili harp hareketleriyle Osmanlı İmparatorluğu'nu tecrit etmişti. Bu durumun ortaya çıkmasında, Balkan ayaklanmalarını destekleyen ve bölgede Osmanlı İmparatorluğu'nun egemenlik haklarını hiçe sayan Çarlık Rusyası özellikle pay sahibi idi. Rusya’ya karşı 1877 yılı başında girişilecek olan 93 Harbi, sonuçları itibariyle imparatorluğu daha da kötü bir duruma sokmuştu. Bu savaş sonucunda Osmanlı İmparatorluğu Balkanlardaki topraklarının ve otoritesinin önemli bir bölümünü kaybetmekle birlikte, siyasi/askeri/mali alanlarda gücü tükenmiş bir devlet durumuna düşmüştü. İşte, yönetimi devraldığı ilk andan itibaren gerek iç politikada devletin çözüm bekleyen ihtiyaçlarıyla, gerekse dış politikada oldukça çetrefilli meselelerle karşı karşıya kalan II. Abdülhamid, Balkan ayaklanmaları, Osmanl1-Rus Harbi, Berlin Kongresi gibi önemli meseleleri bir şekilde atlattıktan sonra, imparatorluğun iç ve dış işlerinde bazı düzenlemeler yapma firsatı bulmuştu. Kabaca 1879 yılından sonrasına denk gelen bu dönemde, Osmanlı bürokratlarının girişimleriyle devlet yönetimini ilgilendiren hemen her alanda 1slahata girişilmiş, imparatorluğun iç ve dış işleriyle ilgili kanunname ve nizamnameler hazırlanarak devlet işlerinin aksamadan yürütülmesi sağlanmaya çalışılmıştı. 1879-1881 döneminde ardı ardına çok sayıda nizamname ${ }^{1}$ hazırlanması, bu anlamda bir tesadüf değildir. 13 Haziran 1881 (15 Receb 1298) tarihinde yürürlüğe giren "Saltanat-1 Seniyye Şehbenderlerine Dâir Nizâmnâme-i Dâhilı̂” de, bu kapsamda değerlendirilmelidir. Bu çalışmada, II. Abdülhamid döneminde Osmanlı İmparatorluğu adına yurtdışında görevli şehbenderlere dair yayımlanan ilk nizamname olan ve şehbenderlik teşkilatına dair önemli bir metin özelliği taşıyan bu nizamname incelenerek, şehbenderlik müessesesinin anlaşılmasına katkı sağlamak amaçlanmıştır.

\section{Osmanlı İmparatorluğu'nda Şehbenderliklerin Teşkili}

XIII. yüzyıl sonlarında, Moğolların tahakkümü altında tarih sahnesinden çekilen Anadolu Selçuklu Devleti'nden sonra küçük bir siyasî teşekkül olarak ortaya çıkan Osmanlı Beyliği, yüz yıldan kısa bir zaman diliminde Anadolu ve Balkanların belirli bölümlerine hâkim bir devlet haline gelmişti (Köprülü 2006: 41). Bizans sınırında teşekkül etmesi ve yönünü Batı'ya çevirmesi sebebiyle diplomasiyi ilk dönemlerden itibaren aktif ve sürekli olarak kullanan Osmanlı Devleti, bilim insanları tarafından "tek taraflı diplomasi”(Akpınar 2001: 5; Akpınar 2014: 60) adı verilen ve "fevkalade elçilik" sistemine dayanan kendine has bir diplomasi kaidesine sahipti. ${ }^{2}$ Buna göre, başta Venedik gibi deniz devletlerinin kullandığı daimi elçilik ve konsolosluk ağının aksine, Osmanlılar ikinci ülkelerle

\footnotetext{
${ }^{1} \mathrm{Bu}$ nizamnamelerin isimlerine ve tarihlerine yer veren bir çalışma için bkz. Akman, M. (2007). Tanzimat'tan Cumhuriyet'e Osmanlı Hukuk Mevzuatı I. Tertip Düstûr'un Tarihî Fihrist ve Dizini. Türk Hukuk Tarihi Araştırmaları, S. 3, 67-224.

${ }^{2}$ Osmanlı diplomasisi konusunda kaynak taramasına yer veren bir çalışma için bkz. Yalçınkaya, M. A. (2003). Kuruluştan Tanzimat'a Osmanlı Diplomasi Tarihi Literatürü. Türkiye Araştırmaları Literatür Dergisi, C. 1, S. 2, 423-489.
} 
fevkalade elçiler vasıtasıyla diplomatik ilişkilere girerek, ihtiyaç duydukları bilgileri bu elçiler aracılığıyla öğrenirlerdi. Her ne kadar geçici elçiliğe dayanan bu diplomatik sistem Osmanlıların “üstünlük anlayışı”yla ${ }^{3}$ ilişkili olsa da, XVII. yüzyıl sonlarından itibaren ciddi şekilde hissedilmeye başlayan diplomatik ihtiyaçlar, Osmanlı Devleti'ni siyasi ve askeri alanda olduğu gibi diplomasi alanında da yeni arayışlara itmiştir. Uzun bir süre kabul edilmek istenilmese de Batı'nın hızlı gelişimine ayak uyduramayan Osmanlı Devleti, Lale Devri’yle başladığı kabul edilen Batılılaşma sürecinde siyasi, askeri ve mali alanlarda olduğu gibi diplomasi alanında da yenileşme çabası içine girmiştir.

1718'de veziriazamlığa getirilen Nevşehirli Damat İbrahim Paşa'nın (1718-1730) bu konudaki gayretleri dikkate değerdir. Sadarette kaldığı on iki yıl müddetince özellikle Avrupa'daki gelişmeleri yakından takip etmek isteyen Damat İbrahim Paşa, bunu diplomatik sahada faaliyet gösteren ve aynı zamanda her biri değerli bilgi kaynakları olan elçiler kanalıyla gerçekleştirmeye çalışacaktır. Damat İbrahim Paşa daha sadaretinin ilk aylarında Defterdar İbrahim Efendi’yi Birinci Murahhas sıfatıyla, Beylerbeyi rütbesiyle ve yedi yüz altmış kişilik maiyyetiyle büyükelçi olarak Viyana Hükümeti nezdine göndermiştir (Uzunçarş11 1982: 148). 1720 yılında ise Tarihçi Râşid'in deyimiyle "Tertib-i muhâverât ve desâyis-i Nasârâ'ya 1ttılâ hâsıl etmiş bir kârdân-1 dakîka-şinas" ${ }^{4}$ olan Yirmisekiz Mehmed Çelebi, Fransa Kralı XV. Louis'ye Sultan III. Ahmed'in selamlarını ileterek, Osmanl1Fransız dostluğunu pekiştirmiştir (Safi 2011: 69-70). ${ }^{5}$ Aynı yıl, mezhep çatışmalarıyla zayıf düşmüş ve iç karışıklıklarla çalkalanan İran'a yine İbrahim Paşa tarafından ticarî görüşmeler yapmak üzere gönderilen Ahmed Dürrî Efendi önemli bilgiler edinmiştir (Safi 2011: 129). 1722 yılında Moskova’ya ortaelçi olarak gönderilen Dergâh-1 Âlî Kapıcıbaşılarından Nişli Mehmed Ağa'nın da meslektaşları gibi diplomatik ve istihbari görevi ön plana çıkmaktadır: Devam eden İran seferi dolayısıyla Rusya’yı İran'a karşı Osmanlı İmparatorluğu'nun yanında yer almaya ikna etmek ve Çarlığın ahvalini gözlemlemek (Safi 2011: 147).

Lale Devri'nde Damat İbrahim Paşa'nın girişimleriyle canlanan bu diplomatik atılımlar, XVIII. yüzyıl sonlarında yenilikçi padişah III. Selim döneminde daha ciddi şekilde ele alınacaktır. Bu dönemde, İngiltere'nin inkişafı ve Fransa'nın ileride sadece Avrupa ile sınırlı kalmayarak Mısır ile Rusya'yı da hedef alacak olan askeri girişimleri, III. Selim'i diplomasi alanında kalıcı adımlar atmaya zorlamıştır. III. Selim özellikle Avrupa'daki siyasi gelişmelerden zamanında haberdar olmak, dünyayı sağlıklı şekilde takip edebilmek ve imparatorluğunu sürekli şekilde temsil ettirebilmek amacıyla ilk

\footnotetext{
${ }^{3}$ Faik Reşit Unat bu sistemi “(...) istilâ devrindeki ihtişamdan kuvvet alan, müstağni infirâd siyaseti” olarak adlandırır; Unat, F. R. (1968). Osmanlı Sefirleri ve Sefaretnameleri. Türk Tarih Kurumu Yayınları, Ankara, 14. ${ }^{4}$ İkili görüşmeleri başarıyla yapabilen ve Hıristiyanların siyaset ve hilelerini iyi bilen.

${ }^{5}$ Kaynaklarda Yirmisekiz Mehmed Çelebi’nin elçilik görevinin yanı sıra 'kaleleri ve imalathaneleri gezmek, medeniyet ve eğitim yöntemlerini kapsamlı bir şekilde incelemek, bunların arasında Osmanlı İmparatorluğu'nda uygulamaya elverişli olanları bildirmek" gibi görevlerinin olduğu kaydedilir; örneğin bkz. Burçak, B. (2012). Osmanlı Sefaret Müessesesi ve 18. Yüzyıl Osmanlı Tarihi: Göçek’e Bir Alternatif. İçinde: Osmanlı Dünyasında Kimlik ve Kimlik Oluşumu, Baki Tezcan-Karl K. Barbir (Der.), Zeynep Nevin Yelçe (Çev.), İstanbul Bilgi Üniversitesi Yayınları, İstanbul, 177-178.
} 
ikamet elçiliklerini kurdurmuştur (1793-Londra) (Karal 1940: 5; Akpınar 2001: 21). İlk şehbenderlikler de aynı düşüncenin etkisiyle ve Osmanlı tüccarlarının Avrupa'daki ticari faaliyetlerini kolaylaştırmak amacıyla önemli Akdeniz ticaret merkezlerinde III. Selim döneminde teşkil edilecektir. ${ }^{6}$ İlk sürekli şehbender ${ }^{7}$ olarak 1802 yılında Sicilya Krallığı'na bağlı Napoli’ye atanan Kefalonyalı Angelo Facetin, bölgedeki Osmanlı tüccarlarının işlerini takip etmek, hak ve hukuklarını gözetmek ve devletin menfaatlerini korumak görevleriyle vazifelendirilmiştir. Napoli’ye yapılan 1802 tarihli bu ilk tayini, 1821'deki Yunan İsyanı'na kadar 16 değişik şehre 25 şehbender ataması takip etmiştir (Akpınar 2017: 131). 1821 Mora Ayaklanmaları sırasında bazı Rum tercümanların diplomatik bilgileri gizlemeleri ve yanlış bilgiler iletmelerinin tespit edilmesiyle, Sultan II. Mahmud elçilik faaliyetleri ile birlikte şehbenderlik faaliyetlerini de yasaklamıştır (Soysal 1990: 72). Dolayısıyla bu tarihten 1836'daki Umur-1 Hariciye Nezareti'nin kurulmasına kadar tüm şehbenderlik faaliyetleri askıda kalmıştır.

Osmanlı Hariciyesi'nde 1836 'da başlatılan yenileşme girişimleriyle şehbenderlik teşkilatı tekrar ele alınmış ve bu alanda yıllar sonra atamalar gerçekleştirilmiştir. 1840 yılında Londra'ya atanan Mösyö Zehrab, Başşehbender sıfatıyla uzun bir müddet sonra atanan ilk şehbender olmuştur. Bir yıl sonra, 1841'de Mösyö Kazimir Amerik adlı gayrimüslim Osmanlı şehbenderi olarak Marsilya'ya gönderilmiş ve bu atamaları diğer görevlendirmeler takip etmiştir (Akpınar, 2001: 22). Tanzimat'ın ilk yıllarına denk gelen 1839-41 aralığında İngiltere'nin Londra ve Malta, Portekiz'in Lizbon, İran'ın Tebriz, Fransa'nın Marsilya ve Nice, Avusturya'nın Fiume ve Trieste, İtalya'nın Cenova, Savona, Spezia, Napoli ve Livorno bölgelerinde Osmanlı şehbenderhaneleri faaliyettedir (Öztuna 1969: 1019; Akdemir 2017: 42).

\section{Tanzimat’tan II. Abdülhamid Dönemi’ne Şehbenderlik Müessesesi}

1839 y1lında ilan edilen Tanzimat Fermanı ile birlikte Osmanlı İmparatorluğu'nun hemen tüm alanlarında olduğu gibi, diplomasi ve dış ilişkiler alanlarında da yeni bir devir açılmıştır. Özellikle bu döneme damgasını vuran Mustafa Reşid Paşa gibi diplomatların Osmanlı Hariciyesi'nde ve merkezi yönetiminde giriştikleri reformlar, 1836'da oluşturulan Hariciye Nezareti'ni giderek daha teşkilatlı ve yetkin hale getirmiştir. Tabii hariciyedeki bu gelişimle birlikte şehbenderhanelerin de sayısı hızla artmış ve bu müessese teşkilat/nitelik olarak gelişim kaydetmiştir. Başlangıçta ticari kaygılarla

\footnotetext{
${ }^{6}$ Şehbender kelimesi terminolojik olarak ticaret kavramıyla yakından ilişkilidir. "Şeh-bender" Farsça ve Arapça iki kelimenin birleşmesiyle oluşmuştur. İlki Farsçada "Hükümdar-Padişah" anlamlarına gelen "Şeh ya da Şah" kelimesi, diğeri ise Suriye ve Mısır Arapçasında "Pazar, Ticaret Yeri, Mübadele Yeri, Sarraflık Merkezi" gibi anlamlara gelen "Bender" kelimesidir. Bu anlamıyla Şehbender kelimesi "Ticaret reisi, Konsolos" gibi kavramlara karşılık gelmektedir; Akpınar, M. (2017). XIX. Yüzyılda Batıyla İlişkilerde Osmanlı Şehbenderlikleri. Cumhuriyet Üniversitesi Sosyal Bilimler Dergisi, C. 41, S. 2, 128.

7 Daha önce, 1725 yılında Kazancızade Ömer Efendi şehbenderlik göreviyle Viyana'ya gönderilmişse de, Kazancızade'nin bu görevi uzun sürmemiş ve bir süre sonra geri çağrılmıştır; bkz. Uzunçarşıllı, İ. H. (1983). Osmanlı Tarihi. C. IV, II. Kısım, Türk Tarih Kurumu Yayınları, 3. Baskı, Ankara, 199; Erol, Y. Z. (2015). Şehbender Raporlarına Göre Osmanlı-Bulgaristan Ticari İlişkileri (1910-1914). Tarih Araştırmaları Dergisi, C. 34, S. 57, 222.
} 
oluşturulan Osmanlı şehbenderhaneleri, XIX. yüzyılın ikinci yarısı boyunca dünyanın birçok bölgesine yayılmıştır. 1839 yılında Ticaret Nezareti'nin kurulmasıyla ticari görevleri büyük oranda bu nezarete bırakılan şehbenderhaneler, bulundukları ülkelerdeki Osmanlı tebaasının evlilikten doğuma, ölümden miras işlerine kadar her türlü idari ve resmi işlemini yaparak kayıt altına almışlardır. Ayrıca XIX. yüzyılın ikinci yarısında Osmanlı İmparatorluğu’nun güvenlik politikaları açısından büyük önem kazanan pasaport işlemlerini usule uygun olarak yerine getirme, bulundukları şehrin basın ve yayın organlarını takip etme, bulundukları ülkeleri gözlemleyerek istihbarat raporları hazırlama gibi kritik görev ve sorumluluklar da şehbenderlerin vazifeleri arasındaydı (Erol 2015: 223-224).

XIX. yüzyılın ikinci yarısına girilirken Osmanlı İmparatorluğu başta İngiltere, Fransa, Felemenk Krallığı, Belçika, İspanya, İtalyan krallıkları ve Alman devletleri olmak üzere birçok ülkeyle konsolosluk ilişkisi kurmuş ve yirmiden fazla kente şehbender tayin etmiştir (Akpınar 2017: 134-135). 1850 y1lında İngiltere'nin Manchester, Liverpool, Birmingham, Newcastle, Fransa'nın Marsilya, Lyon, Bordeaux, İspanya'nın Barselona, Almeria ve Almanya'nın Hamburg gibi önemli kentlerinde Osmanlı şehbenderliklerinin mevcudiyeti bilinmektedir (Öztuna 1969: 1019). Şehbenderlik müessesesindeki gelişim rakamlardan da izlenebilmektedir. Nitekim Tanzimat'ın ilk yıllarında 10 başşehbender ve 15 şehbender çeşitli yabancı kentlerde görev yaparken, bu sayı 1870’lere doğru 26 başşehbender ve 37 şehbendere yükselmiştir (Akpınar 2017: 135).

II. Abdülhamid dönemine gelindiğinde Hariciye alanındaki düzenlemeler devam etmiştir. Sayısal verilere bakılırsa, Sultan II. Abdülhamid'in şehbenderlik müessesesine büyük önem verdiği anlaşılmaktadır. Nitekim XX. yüzyılın arifesinde dünyanın birçok bölgesinde, iki yüzün üzerinde muvazzaf/fahri şehbenderhane Osmanlı İmparatorluğu'na bağlı olarak görev yapmaktadır (Akpınar 2017: 135). 1909'da II. Abdülhamid saltanatı sona ererken, Osmanlı İmparatorluğu'nun İsveç'ten Brezilya'ya, Birleşik Amerika'dan Danimarka'ya kadar dünyanın birçok ülkesinde konsolosluk düzeyinde temsilcisi mevcuttur (Öztuna 1969: 1019-1021). 1881 Nizamnamesi, bu geniş teşkilata ait Sultan Abdülhamid döneminin ilk şehbenderlik nizamnamesi olması bakımından ayrıca incelenmeye değerdir.

\section{Tarihli $^{8}$ Şehbenderler Nizamnamesi}

13 Haziran 1881 tarihinde yayımlanan "Saltanat-1 Seniyye Şehbenderlerine Dâir Nizâmnâme-i Dâhilı̂”, II. Abdülhamid döneminde Osmanlı İmparatorluğu adına yurtdışında görevli şehbenderlere dair yayımlanan ilk nizamnamedir. Bu nizamname ile şehbenderlerin hak, yükümlülük ve görevleri hüküm altına alınmış, imparatorluğun şehbenderhane teşkilatının yapısı belirlenmiştir. Nizamname mevzuattaki değişikliklerle $1886^{9}$ ve $1902^{10}$ tarihlerinde kısmî tadilata uğramış; 1910 tarihli Saltanat-1

\footnotetext{
${ }^{8}$ Nizamnamenin yürürlüğe giriş tarihi Hicri 15 Receb 1298, Rumi 1 Haziran 1297, Miladi 13 Haziran 1881 'dir.

9 "Saltanat-1 Seniyye şehbenderlerine dâir olan nizâmnâme-i dâhilînin 12. maddesi makâmına kâim olmak üzere kaleme alınıp meriyyet-i ahkâmına bi'l-istizân irâde-i seniyye-i cenâb-1 Padişâhî şeref-müteallik buyrulmuş olan madde-i nizâmiye", Düstûr, Tertip/Cilt 1/5, 24 Safer 1304/20 Kasım 1886; ayrıca "Saltanat-1 Seniyye
} 
Seniyye Şehbenderleri Nizâmnâmesi, 1927 tarihli Hariciye Vekâleti Memûrîn Kanunu ve 1938 tarihli Hariciye Vekâleti Teşkilât Kanunu ile tamamen değiştirilmiştir. Tanzimat’tan 23 Nisan 1923 tarihine kadar kabul edilmiş olan kanun, nizamname ve layihalara yer veren ve Osmanlı hukuk mevzuatı için önemli bir kaynak olan Düstûr'da, 192 ilâ 221. sayfaları arasında (Tertip 1, Zeyl 2) bu nizamname yayımlanmıştır. ${ }^{11}$

1881 tarihli Şehbenderler Dahilî Nizamnamesi, üç ana kısımdan oluşmaktadır. Genel hükümleri ihtiva eden nizamnamenin birinci kısmı dört fasla ayrılır ve şehbenderhanelerin teşekkülünden bahseder. Birinci fasıl şehbender memurlarına ait genel hükümlere, ikinci fasıl şehbenderlerin görev yerlerinin özelliklerine, üçüncü fasıl şehbenderlerin vazifelerine ve dördüncü fasıl şehbenderhanelerin teftişine dair maddelerden oluşmaktadır. Nizamnamenin birinci kısma göre daha kısa tutulmuş olan ikinci kısmı şehbenderhanelerde görülecek işlere ait muhasebe işlemlerine, üçüncü kısmı ise fahri şehbenderlere ait hükümlere ayrılmıştır. Nizamnamenin maddelerini şu şekilde inceleyeceğiz:

\section{1) Birinci Kısım: Şehbenderhanelerin Sûret-i Teşekkülü}

Şehbenderlik Sınıfları: 1881 tarihli Şehbenderler Dahilî Nizamnamesi’ne göre biri muvazzaf ve diğeri maaşsız (bilâmaâş) olarak fahri olmak üzere iki çeşit şehbenderlik mevcuttur. ${ }^{12}$ Üç sınıfa ayrılan muvazzaf şehbenderlerden birincileri başşehbender, ikincileri şehbender ve üçüncüleri de şehbender vekili veya kançılarya unvanıyla istihdam edilirler. ${ }^{13}$

Şehbenderlerin Maaş ve Tahsisatı: Osmanlı Devleti tebaası olmaları şart olan muvazzaf şehbenderlerin ticaretle meşgul olmamaları esastır; ayrıca bu tür şehbenderlerin belirli bir miktar maaşları ve memuriyet mahallerinin önemine göre tahsisatı vardır. ${ }^{14}$ Nizamnamenin beşinci bendine göre başşehbenderlere üç bin, şehbenderlere iki bin ve şehbender vekilleri ile kançılarya memurlarına bin lira maaş tahsis olunmuştur. ${ }^{15}$ Bir şehbenderin görevine başlayabilmesi ve maaş alabilmesi için,

şehbenderlerine mütedâir nizâmnâme-i dâhilînin 19 Receb 1298 târihli kısm-1 evvelinin 7, 10, 42 ve 10 Safer 1304 târihli kısm-1 sânîsinin 57. mevâdd-1 muaddeleleri’, Düstûr, Tertip/Cilt 1/5, 27 Rebiülevvel 1304/23 Aralık 1886.

10 "Saltanat-1 Seniyye şehbenderlerine mütedâir 19 Receb 1298 târihli nizâmnâme-i dâhilînin 38 ve 39. mevâdd-1 muaddeleleri”, Düstûr, Tertip/Cilt 1/7, 25 Cemâziyelâhir 1320/ 28 Eylül 1902.

${ }^{11}$ Bkz. "Saltanat-1 Seniyye Şehbenderlerine Dâir Nizâmnâme-i Dâhilîdir", Düstûr, Tertip 1, Zeyl 2, İstanbul, 1299 (1882), s. 192-221.

${ }^{12}$ Birinci bend: "Hey'et-i şehbenderî biri muvazzaf ve diğeri fahrî (bilâmaâş̧) olmak üzere iki nev'idir.", Saltanat1 Seniyye Şehbenderlerine Dâir Nizâmnâme-i Dâhilîdir, Düstûr, Tertip 1, Zeyl 2, İstanbul, 1299 (1882), s. $192-$ 221.

${ }^{13}$ İkinci bend: "Muvazzaf şehbenderler üç sınıfa münkasimdir. Birincisi başşehbender, ikincisi şehbender ve üçüncüsü şehbender vekili vayâhûd kançılarya me'mûrudur.", a.g.e.

${ }^{14}$ Üçüncü bend: "Muvazzaf ve fahrî şehbenderlerin kâffesi bâ-irâde-i şâhânenasb ve ta'yin olunur. Muvazzaf şehbenderlerin tab'a-i Devlet-i Aliyye'den bulunmaları ve ticâretle meşgûl olmamaları meşrûtdur.”; Dördüncü bend: "Muvazzaf şehbenderlere mikdâr-1 muayyen maâş ve mahall-i me'mûriyetlerinin ehemmiyetine göre münâsib mikdâr (allokasyon) tahsîsât i'tâ olunacakdır.", a.g.e.

${ }^{15}$ Beşinci bend: "Şehbenderlerin maâşları ber-vech-i zîr ta'yin olunur 
emir aldığı günden itibaren iki haftaya kadar İstanbul'dan hareketle doğruca memuriyet mahalline gitmesi gerekmektedir. ${ }^{16}$ Bombay ve Batavya Şehbenderlikleri müstesna olmak üzere şehbenderlerin İstanbul'a geliş ve gidiş tahsisatı olarak maaşlarının bir misli miktar belirlenmiştir. ${ }^{17}$ Şehbenderlerin kendilerine ayrılan tahsisattan yapabilecekleri başlıca masraflar, sefarethane giderleri, sefarethane personelinin maaşları ile araba ve sandal masraflarıdır. ${ }^{18}$ Şehbenderhanelerin hükümet tarafından karşılanacak masrafları ise şehbenderhanelerin kirası, sancak ve arma bahası, posta ve telgraf ücretleri, muhtaç Osmanlı tebaasına gerçekleştirilecek yardımlar ve bunların memleketlerine dönüşü için gerekli olan masraflar ile Hariciye Nezareti'nden ya da ilgili sefaretten izin almak kaydiyla yapılacak aciliyet arz eden harcamalardır. ${ }^{19}$

\section{Şehbenderlerin Seçimi, Tayinleri, Özlük Hakları ve Şehbenderlere Uygulanacak Cezalar:}

1881 Şehbenderler Dahilî Nizamnamesi’nde şehbenderlerin seçimi ve çeşitli özlük haklarıyla ilgili hükümler kayıt altına alınmıştır. Nizamnameye göre şehbenderlik mesleğine girebilmek için Hariciye Nezareti Umûr-1 Şehbenderî Müdüriyeti tarafindan yapılacak imtihanda başarılı olmak gerekmektedir. ${ }^{20}$ Şehbenderlik memuriyetleri, Hariciye Nezareti Umûr-1 Şehbenderî Müdüriyeti'nin takriri ve Hariciye Nezareti'nin onayıla belirlenecektir. ${ }^{21}$ Şehbenderlik imtihanına girebilmek için ise Mekteb-i Sultani mezunu olarak Hariciye Nezareti'nde müstahdem olmak veya istihdam olunmak üzere kayıtlı bulunmak gereklidir. ${ }^{22}$ Mekteb-i Mülkiye mezunları ise nizamname-i mahsusa mucibince şehbenderlik imtihanına girmeksizin Sefaret kâtiplikleri ile şehbenderliklere seçilebilirler. ${ }^{23}$

\footnotetext{
Başşehbendere üç bin, şehbendere iki bin, şehbender vekîline veyâhûd Kançılarya me'mûrînine bin kuruş tahsîs olunmuşdur. Şehbenderlerin maâşları mahall-i me'mûriyetlerine vusûlleri târihinden i'tibâren mah ü mah te'diye edilir (...)", a.g.e.

${ }^{16}$ Beşinci bend: “( $\left.\ldots\right)$ şehbenderliğe ta'yin olunan me'mûr mahall-i me'mûriyetine gitmek emrini aldığı günden i'tibâren iki haftaya kadar Dersaâdet'den hareketle doğruca mahall-i me'mûriyetine gitmeğe mecbûr olub aksi takdîrde on yedinci bendde gösterilen cezâya düçâr olacakdır", a.g.e.

${ }^{17}$ Yedinci bend: "Bombay ve Batavya Şehbenderlikleri müstesnâ olmak üzere şehbenderlere azîmet ve avdetlerinde verilecek harcırâh alacakları maâş̧ı bir misli olacakdır (...)", a.g.e.

${ }^{18}$ Onuncu bend: "Tahsîsât dâhilinde verilip şehbenderler tarafindan tesviyesi lâzım gelen mesârif evvelâ kançılarya mesârifi, sâniyen kançllaryada müstahdem me'mûrîn ve kavas ve hademe maâşâtı, sâlisen araba ve sandal mesârifâtından ibâretdir.", a.g.e.

${ }^{19}$ On birinci bend: "Hükûmet-i seniyye tarafından kabûl ve i'tâ olunacak mesârif

Evvelâ şehbenderhâne icârı, sâniyen sancak ve arma bahası, sâlisen posta ve telgraf ücretleri (resmî mektûb ve paket ve telgraf için), râbian yirmi dokuzuncu bendde muharrer ta'lîmâtda ta'yîn olunan haddı tecâvüz etmemek üzere tab'aya iâne ve bunların memleketlerine iâdeleri için muktazi olan mesârif, hâmisen şehbenderin merbût olduğu sefâret-i seniyyeden veyâhûd Nezâret-i Hâriciye'den bi'l-istizân ruhsat-1 mahsûsa ile edilecek mesârif-i sâire-i acileden ibâretdir.”, a.g.e.

${ }^{20}$ On ikinci bend: "Şehbenderlik silkine duhûl Nezâret-i Hâriciye Umûr-1 Şehbenderî Müdüriyeti mârifetile şerâit-i mevzûası mûcibince icrâ olunacak müsâbakât imtihânı ile vukû'bulacakdır (...)", a.g.e.

${ }^{21}$ On ikinci bend: “(...) Şehbenderlik me'mûriyetleri Müdüriyet-i mezkûre tarafindan tanzîm edilen takrîr üzerine Nezâret-i Hâriciye'nin tasvîb ve intihâbı ile icrâ olunacakdır (...)", a.g.e.

${ }^{22}$ On ikinci bend: “(...) Mekteb-i Sultânî’de ikmâl-i tahsîl edib yedlerinde şehâdetnâmeleri olarak Hâriciye Nezâreti'nde müstahdem bulunan veyâhud istihdâm olunmak üzere mukayyed ve mülâzım olanlar işbu müsâbakât imtihânına duhûl hakkını hâizdirler (...)", a.g.e.

${ }^{23}$ On ikinci bend: “(...) Mekteb-i Mülkiye şehâdetnâmesini hâiz olanlar nizâmnâme-i mahsûsa mucibince müsâbakât imtihânına girmeksizin sefâret kitâbetleri ile şehbenderliklere intihâb olunurlar.”, a.g.e.
} 
Şehbenderlerin azilleri, terfileri ve başka bir mahalle ya da memuriyete nakilleri padişah iradesiyle gerçekleşir. ${ }^{24}$ Muvazzaf şehbenderler diğer mülkiye memurları gibi belirli şartları taşımaları halinde emekli maaşı alabilirler. ${ }^{25}$ Şehbenderler savaş halinde veya herhangi bir diğer sebeple ya da Hariciye Nezareti'nce geçici olarak başka bir yere gönderilip görev yerlerini terk edecek olurlarsa, Hariciye Nezareti'nin emri altında bulunmaya devam edeceklerinden, maaş almaya da devam edebileceklerdir. ${ }^{26}$

Şehbenderlere uygulanacak cezai işlemler ile ne tür fiilerin hangi ceza ile tecziye edileceği nizamnamede belirlenmiş̧ir. Buna göre vazife ifasında gevşeklik gösterenler, memuriyet hilafina hareket edenler veya memuriyet sıfatına yakışmayan hareketlerde bulunanlar öncelikle tevbih (uyarı) edilir; fakat bu tür fiillerin devamı halinde bir aydan bir seneye kadar vazifeden azil ile maaşın bir kısmının ya da tamamının kesilmesi cezası uygulanabilir. ${ }^{27}$ Ceza gerektiren kabahati işlemekte 1 srar edenler ve memuriyet vazifesini ağır surette ihlal edenler ise, şehbenderlik vazifesinden çıkarılır. ${ }^{28}$ Memuriyeti sırasında edindiği bilgileri gerektiği gibi gizlememek, kayıtlarda tahrif, hesap işlerinde sahtekârlık ve -vasıtalı veya vasıtasız- ticaretle meşgul olmak gibi fiiller şehbenderler için ağır vazife kusurlarından addolunur. ${ }^{29} \mathrm{Bu}$ tür kusurları işleyenler amirleri tarafindan Hariciye Nezareti'ne ihbar edilir; ihbar sonrası kısa süreliğine de olsa işten el çektirilen (muvakkaten azl) şehbenderler, eğer izahat vermek isterlerse, ilgili sefaretten ya da Hariciye Nezareti'nden izin talep edebilirler. ${ }^{30}$

\footnotetext{
${ }^{24}$ On üçüncü bend: "Şehbenderlerin azli veyâ diğer mahalle nakl-i me'muriyetleri bâ-irâde-i seniyye icrâ olunur.", a.g.e. ; On dördüncü bend: "Şehbenderlerin terfi-i me'mûriyetleri intihâb ile bâ-irâde-i şâhâne icrâ olunur.", a.g.e.

${ }^{25}$ On beşinci bend: "Muvazzaf şehbenderlerin tekâüdlük maâşı me'mûrin-i sâire-i mülkiye hakkında olan nizâmnâmede musarrah esbâb ve şerâite tevfîkan i'tâ olunur.", a.g.e.

${ }^{26}$ On altıncı bend: "Şehbenderler muhârebe vukuu veyâhûd sâir esbâb-1 mücbire zuhûru veyâhûd Nezâret-i Hâriciyece muvakkaten bir me'mûriyetde istihdâm olunmaları lâzım gelmesi gibi bilâ- ihtiyâr bulundukları me'mûriyeti terk ve ta'tîl etdikleri takdîrde Hâriciye Nezâreti'nin emri tahtında bulunacaklarından maâşları yine kendilerine i'tâ olunacak[dır](...)", a.g.e.

${ }^{27}$ On yedinci bend: "Şehbenderler hakkında icra olunacak mücâzât-1 inzibâtiye şunlardır: Evvelâ tevbih, sâniyen bir aydan bir seneye kadar azl-i muvakkat ile maâşının kısmen veya külliyen kat'ı, sâlisen me'mûriyetden affi.

Şu ta'dâd olunan mücâzâtdan birine düçâr olan şehbenderlerin nev'-i cezâsı Umûr-1 Şehbenderi Müdüriyeti'nde bulunan me'mûrîn defterlerine işâret olunacakdır.", a.g.e.

${ }^{28}$ On dokuzuncu bend: "On yedinci bendde gösterilen birinci ve ikinci nev'i cezâ evvelâ ifâ-yı vâzifede tekâsül veyâhûd hilâf-1 me'mûriyet veyâ hüsn-i inzıbâta karşı hareket edenler ve sâniyen sıfât-1 me'mûriyetine yakışmayacak bir meslek ihtiyâr eyleyenler haklarında icrâ olunur. Me'mûriyetden af cezâsı evvelâ tevbih cezâsını müstelzim olan kabâhati tekrârda temerrüd eden ve sâniyen ifâ-yı vâzifede itiyâdı tekâsül veyâ vezâif-i me'mûreyi ağır sûretle ihlâl edecek harekete tasaddi eyleyenler hakkında câridir.", a.g.e.

${ }^{29}$ On dokuzuncu bend: "Vezâif-i me'mûreyi ağır sûretle muhill addolunan harekâtın başlıcaları evvelâ umûr-1 me'mûreye müteferri esrârı ketm u ihfầ etmemek, sâniyen kuyûdâtın vaz'-1 aslîsini tağyir etmek veya umûr-1 hesâbiyede sahtekârlık, irtikâb eylemek (sahtekârlık için mehâkim-i cezâiyede kânûnen edilecek cezânın buna taalluku olmayacakdır), sâlisen bilvâsita veyâ bilâvâsita ticâretle meşgûl olmak husûslarıdır.", a.g.e.

${ }^{30}$ Yirmi birinci bend: "On dokuzuncu bendin birinci ve ikinci maddelerine tevfîkân hilâf-1 me'mûriyet hareket eden şehbender âmiri tarafindan muvakkaten azledilebilecek ve keyfiyet Hâriciye Nezâreti'ne ihbâr edilecekdir. Muvakkaten azledilen me'mûr mesleki müttehâzı üzerine izâhat vermek ister ise maiyyetinde bulunduğu sefâret-i seniyye veyâhûd Nezâret-i Hâriciye'den ruhsat taleb edecekdir.", a.g.e.
} 
Şehbenderlerle Muhaberat: Görevde bulunan her şehbender, bulunduğu mahallin mensup olduğu devlet nezdinde vazifeli sefarete mensuptur. Bulunduğu mahallin devleti nezdinde sefaret bulunmayan şehbenderler Hariciye Nezareti maiyyetinde bulunurlar. ${ }^{31}$

Şehbenderlerin bağlı bulundukları sefaretlerle teati edecekleri muhaberat üç kısımdır. Şehbenderler öncelikle bulundukları mahalde, mahalli hükümet ile nihayete erdiremedikleri ihtilafları, ikincisi, vazifeli oldukları bölgede ortaya çıkan ve derhal sefaretin müdahalesini gerektiren ticari ve siyasi vukuatı ve üçüncü olarak da bu nizamnamede kayıtlı bulunmayan ve kendilerince tereddüt ve şüphe ortaya çıkaracak meseleleri sefaretlere bildireceklerdir. ${ }^{32}$ Şehbenderlerle Hariciye Nezareti arasında yapılacak başlıca muhabere konuları ise, hükümetin resmi dairelerini ilgilendiren meseleler, doğum, ölüm, nikâh, veraset, seyrüsefain işleri ile acil ve mühim politika işlerinden oluşmaktadır. ${ }^{33}$

Şehbenderlerin Görev Mahalleri: Nizamnamenin birinci kısmının ikinci faslı, şehbenderlerin görev mahallerini belirlemiştir. Buna göre başşehbenderin görev yaptığı mahal vilayet, şehbenderin görev yaptığı mahal liva, şehbender vekilinin görev mahalli şehbenderlerin görev mahalleri dâhilinde olan livadır. ${ }^{34}$ Bir vilayet veya livada re'sen memur olan şehbender maiyyetindeki bütün memurların amiridir. ${ }^{35}$ Şehbenderhane memurları, amirlerinin emrine itaatle mükelleftirler. ${ }^{36}$ Şehbender vekilleri, başşehbender ya da şehbenderlerin nezareti altında vazifelerini ifa ve mesuliyetleri çerçevesinde şehbenderhaneye gelen evrakı imza edeceklerdir. ${ }^{37}$

Şehbenderlerin Görevleri: Şehbenderler tebaa hakkında idari işlemlerle ilgili ve mukavelat muharrirliğine ait vazifeleri ifa ederler ve tebaanın doğum, vefat ve nikâh gibi işlerini yürütürler. Bu vazifelerin teferruatına dair gerekli talimat Hariciye Nezareti tarafından tanzim edilerek şehbenderlere gönderilir. ${ }^{38}$ Şehbenderler bu işlemler sırasında muahedat ve muhavelat hükümlerinin tamamen

\footnotetext{
${ }^{31}$ Yirmi ikinci bend: "Me'mûriyetde bulunan her şehbender bulunduğu mahallin mensûb olduğu devlet nezdine terhîs olunmuş olan sefâret-i seniyyeye merbûtdur. Bulundukları mahallin mensûb olduğu devlet nezdinde sefâret bulunmayan şehbenderler Hâriciye Nezâreti maiyyetinde bulunurlar.", a.g.e.

${ }^{32}$ Yirmi üçüncü bend: "Şehbenderlerin merci'leri olan sefâret-i seniyyelerle teâti edecekleri muhaberât: Evvelâ hükümet-i mahalliye ile bir nihâyete îsâle muvaffak olamadıkları ihtilâfâtdan ve sâniyen havza-i idâreleri dâhilinde zuhûra gelen ve derhâl veyâ bilâhare sefâret-i seniyyenin müdâhalesini istilzâm edecek olan vuku'ât-1 ticâriye ve siyâsiyeden ve sâlisen işbu nizâmnâmede münderic bulunmayan ve kendilerince dâî-i tereddüd ve iștibâh olan hâlât-1 sâire-i nâgeh-zuhûrdan ibâretdir.", a.g.e.

${ }^{33}$ Yirmi dördüncü bend: "Şehbenderlerin Hâriciye Nezâreti ile teâti edecekleri muhaberât: Evvelâ hükûmet-i seniyye devâir-i resmiyyesinden birine taalluku bulunan mesâlihdir. Ve sâniyen velâdet ve vefîyât ve münâkehât ve verâset ve seyr-i sefâin işlerinden ve sâlisen politika umûr-1 müsta'cele ve mühîmmesinden ibâretdir.", a.g.e.

${ }^{34}$ Yirmi beşinci bend: "Başşehbenderin hakk-1 kazâsını muhît olan dâireye vilâyet denir. Bir şehbenderin hakk-1 kazâsını muhît olan dâireye livâ denir. Şehbender vekîlinin hakk-1 kazâsı bir şehbenderin havza-i me'mûriyetini hâvî olan livâ dâhilindedir(...)", a.g.e.

${ }^{35}$ Yirmi altıncı bend: "Bir vilâyet veya livâda re'sen me'mûr olan şehbender maiyyetinde bulunan bilcümle me'mûrların âmiridir (...)", a.g.e.

${ }^{36}$ Yirmi altıncı bend: “( (..) Bunların her hâlde emirlerine itâatla mükellefdirler.”, a.g.e.

${ }^{37}$ Yirmi sekizinci bend: "Maiyyet me'mûriyetinde bulunan şehbender vekîli başşehbender veya şehbender nezâret-i tahtında ifâ-yı me'mûriyet eyleyecek ve vekâleti zamânında yirmi dokuzuncu bendde zikrolunan ta'limâtda gösterildiği vechile kendi mes'ûliyeti tahtında şehbenderhâneye gelen evrâkı imzâ edecekdir.", a.g.e.

${ }^{38}$ Yirmi dokuzuncu bend: "Şehbenderler teb'a hakkında idâre-i me'mûriyetine müteallik ve mukâvelât muharrirliğine âid vezâifi ifâ ve teb'anın velâdet ve vefîyât ve münâkehâta dâir işlerini rü'yet eyler. İşbu vezâifin
} 
icrasına, hükümetin menfaatlerinin himayesine ve Osmanlı sancağına riayet edilmesine dikkat ve itina edeceklerdir. ${ }^{39}$ Bunun dışında şehbenderler ticaret, sanayi ve genel sağlık gibi ammenin menfaatini ilgilendiren konularla ilgili edindikleri izlenim ve malumatı hükümetle paylaşacaklardır. Bu maksatla şehbenderler mahalli hükümetle, ahali muteberanıyla ve yabancı devletler konsolosları ile mütemadiyen münasebetlerde bulunacaklardır. ${ }^{40}$

Şehbenderlerin bu nizamnamede kayıt altına alınan en önemli görevlerinden biri de, gizli politika meclislerini Osmanlı memleketinin genel güvenliğini ilgilendirdiği ölçüde tahkik/takip etmek ve sair cihetlerce tehlikesi mütevatir (tevatir eden) ve müssellem (doğru kabul edilen) olan şahıslar bulunduğu takdirde onların da fiil ve hareketlerini tecessüs (izleme) etmektir. ${ }^{41}$ Ayrıca şehbenderler memuriyetlerinin bu nazik cihetini yerine getirebilmek için icabında hafiye memuru istihdam edebilecekler ise de, bu konuya mahsus izni ve lazım olan meblağı öncelikle maiyyetinde bulundukları sefaretten talep edeceklerdir. ${ }^{42}$ Özellikle altını çizmek gerekir ki bu madde, şehbenderlere istihbarat çalışmaları yapma ve istihbari bilgileri paylaşma konusunda önemli bir yetki ve sorumluluk devretmektedir. Nitekim II. Abdülhamid dönemi boyunca dünyanın dört bir yanından Hariciye Nezareti'ne sayısız istihbari bilgi ulaştırılmasının, hükümetin bu şekildeki teşvikleriyle sağlandığı açıktır.

Şehbenderlerin görevlerine dair nizamnamede yer alan "Şehbenderlerin vezâif-i me'mûreleri" başlıklı üçüncü faslın otuz üçüncü bendinde, şehbenderlerin mahalli matbuatı dikkatle takip etmekle vazifeli oldukları ve eğer mahalli matbuatta padişah ya da hükümet aleyhine muzır neşriyat tespit ederlerse mahalli hükümeti münasip lisanla uyarıp bağlı bulundukları sefareti bilgilendirmeleri hüküm altına alınmıştır. ${ }^{43}$ Ayrıca şehbenderhanelerin bu tür yayınlar yapan matbuat aleyhine mahkemelerde dava açabilmeleri için, sefaretin onayını almaları gerekmektedir. ${ }^{44}$ Sefaretin izni olmadan bu tür

teferruâtına dâir icâb eden ta'limât Hâriciye Nezâreti tarafından bit-tanzîm şehbenderlere gönderilecekdir.", a.g.e.

${ }^{39}$ Otuzuncu bend: "Şehbenderler muâhedât ve muhâvelât ahkâmının tamâmi-i icrâsına ve hükûmet-i seniyye menâfiinin himâyesine ve Devlet-i Aliyye sancağına riâyet edilmesine dikkât ve i'tinâ edeceklerdir.", a.g.e.

${ }^{40}$ Otuz birinci bend: "Şehbenderler ticâret ve sanâyi ve sihhat-i umûmiye gibi bir sûret-i mahsûsada menfaat-i âmmeye müteallik kâffe-i ma'lûmât ve ıttıla'âtlarını hükûmet-i seniyyeye i'tâ edeceklerdir. İşbu maksadın husûlü için hükûmet-i mahalliye ve muteberânı ahâli ve düvel-i ecnebiye konsolosları ile münasebât-1 mütemadiyede bulunacaklardır.", a.g.e.

${ }^{41}$ Otuz ikinci bend: "Şehbenderler politika mecâlis-i hafîyyelerinin harekât ve ilkaâtını memâlik-i şâhânenin istirahat-i umûmiyesine taalluku bulunduğu derecede tahkîk ve tecessüs eyleyecekler ve sâir cihetlerce mazarrât ve tehlikesi mütevâtir ve müssellem olan eşhâs bulunduğu takdirde onların dahî ef'âl ve harekâtını tecessüs eyleyeceklerdir (...)", a.g.e.

${ }^{42}$ Otuz ikinci bend: “(...) Umûr-1 me'mûresinin işbu cihet-i nazîkesini îfâ için icâbı takdirinde hafîyye me'mûru istihdâm eyleyecekler ise de bu bâbda ruhsat-1 mahsûsa ve mebâliğ-i lâzımeyi evvelemirde maiyyetinde bulundukları sefâret-i seniyyeden taleb eyleyeceklerdir.", a.g.e.

${ }^{43}$ Otuz üçüncü bend: "Şehbenderler matbûât-1 mahalliyyeye dikkât-i mütemadiye icrâsı ile Zât-1 Şevketsimât Hazret-i Pâdişâhîye ve hükûmet-i seniyyelerine karşsı neşriyât-1 muzırrada bulunanların te'dîbleri için hükûmet-i mahalliyyeye lisân-1 münâsib ile ihtârât-1 lâzımeyi îfâ edecekler (...)", a.g.e.

${ }^{44}$ Otuz üçüncü bend: "(...) [şehbenderler] ve fakat maiyyetinde bulundukları sefâret-i seniyyeden evvelce istizân etmedikçe bu makûle türrehât ilânına cür'et eden matbûât aleyhine mahâkimde ikâme-i dâvâ edemeyeceklerdir.", a.g.e. 
matbuatla mücadeleye girişmek şehbenderler için kesinlikle yasaktır. ${ }^{45}$ Bunun dışında şehbenderlerin matbuat konusundaki önemli bir görevleri de, gazetelerin Osmanlı Devleti aleyhine yayınladıkları ehemmiyetli yazıları Türkçe veya Fransızcaya tercüme ederek şehbenderhanenin mercii olan sefarete ve çok önemli bir yazı ise doğrudan doğruya Hariciye Nezareti'ne göndermektir. ${ }^{46}$

Şehbenderhanelerin Teftişi: Nizamnamenin devamı, şehbenderhanelerin teftişine dair hükümleri belirler. Buna göre nizamnamenin uygulamaya konulma tarihinden bir sene sonra ve sonrasında her beş senede bir kere Hariciye Nezareti tarafından tayin olunacak müfettiş marifetiyle birinci, ikinci ve üçüncü sınıf şehbenderhaneler teftiş edilir. ${ }^{47} \mathrm{Bu}$ teftişler sırasında bir şehbenderin idaresinde ve vilayetin muhtelif mahallinde bulunan fahri şehbenderhaneler de görevli müfettişler tarafından teftiş edilip, teftiş sonuçları mufassalan şehbenderhanenin mercii olan sefarete bildirilir. ${ }^{48}$

\section{2) İkinci Kısım: Muhasebe}

\section{Şehbenderler Tarafindan Alınacak Vergi ve Ücretler: 1881 Şehbenderler Dahilî}

Nizamnamesi’nin kırkıncı ilâ elli yedinci bendleri arasındaki bölüm şehbenderhanelerin muhasebe işlemleri ile şehbenderlerin işlemler karşılığında devlet adına alacakları ücretlere değinmektedir. Nizamnameye göre muvazzaf veya fahri şehbender memurları tarafından verilecek veya imzalanacak resmi evrakın tümüne, Hariciye Nezareti tarafından peyderpey gönderilecek ve ahzolunacak vergi miktarını gösteren pullardan yapıştırılacaktır. ${ }^{49}$ Şehbenderler tarafından verilen veya imzalanan resmi evraka pul yapıştırılmamış ise, bu tür evrakın geçerliliği olmayacaktır. Bu tür pulsuz evraktan dolayı alakadar olanların uğrayacakları zarar ve ziyandan şehbender mesul olacak ve sorumlu şehbender, işlemin ehemmiyetine göre belirlenen cezalara uğrayacaktır. ${ }^{50}$

Şehbenderhanelerde kullanılacak pullar altı çeşit olup birincisi 50, ikincisi 20, üçüncüsü 10 , dördüncüsü 5 kuruş ve beşincisi 20 para kıymetinde olacak ve altıncısı sıfır işaretini muhtevi olarak

\footnotetext{
45 Otuz dördüncü bend: "Şehbenderlerin merbût oldukları sefâret-i seniyye cânibinden ruhsat olmadıkça matbûât-1 mevgûte-i mahalliyye ile zuhûr edecek mücâdelelere iştirâk etmeleri kat'iyyen memnûdur.”, a.g.e.

${ }^{46}$ Otuz altıncı bend: "Gazetelerin Devlet-i Aliyye aleyhine derc ve neşr etdikleri ehemmiyetli bendler Türkçe veya Fransızcaya tercüme olunarak şehbenderhânenin mercii olan sefâret-i seniyyeye ve ehemmiyeti pek ziyâde ise doğrudan doğruya Nezâret-i Hâriciyeye gönderilecektir.", a.g.e.

${ }^{47}$ Otuz sekizinci bend: "İş̧bu nizâmnâmenin mevki'-i icrâya vaz'ı târihinden bir sene sonra ve ba'de her beş senede bir kerre Nezâret-i Hâriciye cânibinden ta'yin olunacak müfettiş ma'rifetiyle birinci ve ikinci ve üçüncü sınıf şehbenderhâneler teftîş olunacakdır (...)", a.g.e.

${ }^{48}$ Otuz sekizinci bend: “(...) O esnâda bir şehbenderin zîr-i idâresinde ve vilâyetin mahall-i muhtelifesinde bulunan fahrî şehbenderhâneler dahî mûmâ-ileyh tarafindan teftîş olunub netîce-i müstahsile mufassalan mercii olan sefâret-i seniyyeye bildirilecekdir.", a.g.e.

${ }^{49}$ Kırkıncı bend: "Muvazzaf veya fahrî șehbender me'mûrları tarafından verilecek veya imzâ edilecek evrâk-1 resmiyyenin kâffesine ahzolunan resim mikdârını mübeyyin Hâriciye Nezâreti cânibinden peyderpey gönderilecek pullardan yapışdırılacakdır.”, a.g.e.

${ }^{50}$ Kırk birinci bend: "Şehbenderler tarafından verilen veya imzâ edilen evrâk-1 resmiyyenin pul yapışdırılmamış ise aslâ hüküm ve i'tibârı olmayacakdır. Bu makûle pulsuz evrâkdan dolayı alâkâdâr olanlara terettüb eden zarâr ve ziyândan şehbender mes'ûl olacak ve bundan maâda ehemmiyet-i maslahata göre bâlâda beyân olunan mücâzâta dûçâr olacakdır.", a.g.e.
} 
ücretsiz verilen resmi evraka yapıştırılacaktır. ${ }^{51}$ Muvazzaf veya fahri şehbenderler kullandıkları pulların hesabını her üç ayda bir Hariciye Nezareti'ne gönderecekler ve kullanılmayan pulları her altı ayda bir nezarete iade edeceklerdir. Ayrıca şehbenderlerin verdikleri pasaport ve tasdikname vesair matbu evrak Hariciye Nezareti tarafından gönderilecektir. ${ }^{52}$

Nizamnamede pasaport, vize ve çeşitli vergilere dair ücretler de belirlenmiştir. Buna göre pasaport resmi 50 kuruş, vize resmi 20 kuruş, elli tonilatodan az olan sıhhiye patentesinin vize resmi 10 kuruş, elli tonilatoyu aşan sıhhiye patentesinin vize resmi 20 kuruştur. ${ }^{53}$ Bununla birlikte kançılaryada bulunan memur tarafından tarifeden fazla vergi alınmamasına şehbenderler dikkat edecekler ve tarifede belirlenmemiş resmi evrak ücretsiz olarak verilip, derhal Hariciye Nezareti'ne bilgi verilecektir. ${ }^{54}$

Husus (vakasyon) müddeti üç saattir. Bu müddetten önce son bulan husus için tam vergi alınır. Husus esnasında tanzim olunan zabıtname müsveddeleri için vergi alınmayacak; yazdırılan resmi evrakın her biri için ise suret harcı alınacaktır. ${ }^{55}$ Âdetler ve belde nizamları iktizasınca ayrıca tediyesi gerekli olan mağaza ücreti, hekim, hesap işleri ve bilirkişi masrafları gibi şeyler şehbenderler tarafından verilen evrak için alınan vergi dâhilinde değildir. ${ }^{56}$

Harcırah, Hasilat ve Masraflar: Özel memuriyetle veya bir töhmet ve cinayet vukuunda sorgulama icra etmek için aldığı emir üzerine memuriyet mahallinden diğer mahalle giden şehbenderlere verilmesi gerekli olan harcurah ile şehbenderlerin gittikleri mahaldeki ikameti müddetinde ortaya çıkacak masraflar Osmanlı hükümeti tarafından karşılanacaktır. ${ }^{57}$ Harcırahlar, alakadar olanlar tarafindan peşin olarak verilecektir. ${ }^{58}$

\footnotetext{
${ }^{51}$ Kırk ikinci bend: "Pullar altı nev' olub birincisi 50 ikincisi 20 üçüncüsü 10 dördüncüsü 5 kuruş ve beşincisi 20 para kıymet irqe edecek ve altıncısı sıfır işâretini muhtevî olarak meccânen veya bilâ mesârif verilen evrâk-1 resmiyyeye yapışdırılacakdır. Bir pul kıymetinin nısfı mukâbilinde yarım pul isti'mâli câiz değildir.", a.g.e.

${ }^{52}$ Kırk üçüncü bend: "Muvazzaf veya fahrî şehbenderler isti'mâl etdikleri pulların hesâbını her üç ayda Hâriciye Nezâretine irsâl eyleyecekler ve isti'mâl olunmayan pulları her altı ayda Nezâret-i müşârûnileyhâya iâde edeceklerdir. Taraf-1 Nezâretden dahî yeniden pul gönderilecekdir.”, a.g.e.

${ }^{53}$ Kırk beşinci bend: "Meriyyü'l-icrâ olan tarife ber-vech-i âtî ta'dîl olunmuşdur:

Pasaport resmi . .50 Kuruş

Vize resmi..... 20 Kuruş

Elli tonilatodan dûn olan sihhiye patentesinin vize resmi....10 Kuruş

Elli tonilatodan ziyâde sıhhiye patentesinin vize resmi.....20 Kuruş

Rüsûm-u sâirenin kâffesine yüzde on zam olunmuşdur.", a.g.e.

${ }^{54}$ Kırk yedinci bend: "Kançılaryada bulunan me'mûr tarafından tarîfeden fazla resim ahzedilmemesine şehbenderler dikkât edecekler ve tarîfede musarrah olmayan evrâk-1 resmiyye meccânen verilip derhâl Nezâret-i Hâriciyeye ihbâr-1 keyfiyet eyleyeceklerdir.”, a.g.e.

${ }^{55}$ Kırk dokuz, elli, elli birinci bendler: "Husus (vaksiyon) müddeti üç saatdir. Müddet-i muayyeneden evvel hitâm bulan husus için tam resim ahzolunur. Husus esnâsında tanzîm olunan zabıtnâme müsveddeleri için bir güna resim ahzolunmayacakdır. İstinsâh etdirilen evrâk-1 resmiyyenin her biri için sûret harcı istifâ olunur.", a.g.e.

${ }^{56}$ Elli ikinci bend: "Âdât ve nizâmât-1 belde iktizâsınca ayrıca tediyesi lâzımgelen mağaza ücreti ve hekim ve rü'yet-i hesâb ve ehl-i hibre mesârifi gibi şeyler şehbenderler tarafindan verilen evrâk için ahzolunan rüsûm dâhilinde değildir.", a.g.e.

${ }^{57}$ Elli üçüncü bend: 'Me'mûriyet-i mahsûsa ile veyahud bir töhmet ve cinâyât vuku'ûnda icrâ-yı istintâk için aldığı emir üzerine mahall-i me'mûriyetinden diğer mahalle azîmet eden şehbenderlere verilmesi lâzımgelen
} 
Şehbenderhanelerin masrafları düşüldükten sonra fazla hasılat her üç ayda en yakın ve basit yolla Hariciye Nezareti'ne gönderilecektir. ${ }^{59}$ Masraf defterleri senetler ile beraber her üç ayda bir Hariciye Nezareti'ne gönderilecektir. ${ }^{60}$ Fahri şehbenderlere ait olan şehbenderhane masraflarına karşı11k olmak üzere y1llık beş yüz kuruş kadar olan hasılat tümüyle ve beş yüzden on bin kuruşa kadar olan hasılatın beş yüz kuruşunun tamamı ve kalan kısmının yarısı kendilerine terk olunacak ve hasılat on bin kuruşu aştığında fazlası tamamıyla Hazineye ait olacaktır. Talimata kaydedilen şartlara uygun olarak memleketlerine gönderilecek muhtaç tebaa için ortaya çıkacak masraflar, devlete ait olacak hasılattan ve hasılat yok ise devlet tarafından karşılanacaktır. ${ }^{61}$

\section{3) Üçüncü Kısım: Fahri Şehbenderlere Dair Hükümler}

Nizamnamenin üçüncü kısmı fahri şehbenderlere dair hükümlere ayrılmıştır. Buna göre fahri şehbenderler başşehbender, şehbender ve şehbender vekillerinden ibarettir. ${ }^{62}$ Fahri şehbenderlerin maaşları olmayıp şehbenderhane hasılatından ücret alacaklardır. ${ }^{63}$ Fahri şehbenderler mercileri olan sefaretin teklifi üzerine padişahın iradesi ile nasbolunurlar, imtihan edilmezler. Ayrıca yerli halktan veya ecnebi tebaa muteberanından seçilerek ticaretle meşgul olabilirler. Fakat bunların bulundukları mahalden başka bir memlekette görevlendirilmeleri uygun değildir. ${ }^{64}$

Fahri şehbenderler kançılarya masraflarını kendileri tesviye etmeye mecburdurlar. Yalnız memleketlerine iade olunacak muhtaç tebaanın masrafları ile posta ve telgraf ücretleri hükümet namına olarak hasılattan tesviye edilir. ${ }^{65}$ Fahri başşehbenderler mukim oldukları memlekette bulunan sefarete bağlı olup fahri şehbenderler de silsile-i merâtib kaidesine uygun olarak muvazzaf

harcırâh ile orada ikâmeti müddetinde vuku'bulacak mesârif hükûmet-i seniyye tarafindan i'tâ edilecek (...)", a.g.e.

${ }^{58}$ Elli Üçüncü bend: “(...) ve ahvâl-i sâirede harcırâh alâkâdâr olanlar tarafindan peşîn olarak verilecekdir.”, a.g.e.

${ }^{59}$ Elli beşinci bend: "Şehbenderhânelerin mesârif-i mukânnenesi tenzîl olundukdan sonra fazla hâsılât her üç ayda en yakın ve ehven tarîkle Hâriciye Nezâreti'ne gönderilecekdir.", a.g.e.

${ }^{60}$ Elli altıncı bend: "Mesârifat defterleri ihticâca sâlih senedât ile berâber her üç ayda Hâriciye Nezâreti'ne irsâl olunacakdır.", a.g.e.

${ }^{61}$ Elli yedinci bend: "Fahrî şehbenderlerin taraflarına âid bulunan şehbenderhâneler mesârifine mukâbil olmak üzere senevî beş yüz kuruş kadar olan hâsılâtı kâmilen ve beş yüzden on bin kuruşa kadar vukûbulan hâsılâtın beş yüz kuruşunun tamâmı ve evsat tarafinın nısfı kendilerine terk olunacak ve hâsılât on bin kuruşu tecâvüz etdiği halde fazlası tamamı ile Hazine-i Celîleye âid bulunacakdır. Nizâmı dâiresinde sâbit olacak posta ve telgraf ücretleri talimâtda münderic şerâide tevfikân memleketlerine iâde edilecek muhtâcin teb'a için vukûbulacak mesârifler devlete âid olacak hâsılâtdan ve hâsılât yok ise taraf-ı devletden tesviye kıılınacakdır.”, $a$ .g.e.

${ }^{62}$ Elli sekizinci bend: "Fahrî şehbenderler başşehbender ve şehbender ve şehbender vekîllerinden ibâretdir.", a.g.e.

${ }^{63}$ Elli dokuzuncu bend: "Fahrî şehbenderlerin maâşları olmayıb elli yedinci bendde mezkûr cedvelde ta'yin olunan mikdâr akçe hâslâtdan ahz-utevkîf edeceklerdir.", a.g.e.

${ }^{64}$ Altmışıncı bend: "Fahrî şehbenderler mercileri olan sefâret-i seniyyenin teklifi üzerine ba-irâde-i şâhâne nasbolunur. Fahrî şehbenderler yerliden veya teb'a-i ecnebiye muteberânından intihâb olunarak ticâretle meşgûl olabilirler fakat bunların bulundukları mahalden diğer memlekete nakl-i me'mûriyetleri câiz olamaz. Fahrî şehbenderler imtihân edilmeyeceklerdir.”, a.g.e.

${ }^{65}$ Altmış birinci bend: "Fahrî şehbenderler kançılarya mesârifini kendileri tesviye etmeğe mecbûrdurlar. Yalnız memleketlerine iâde olunacak muhtâcîn-i teb'anın masrafları ile posta ve telgraf ücretleri hükûmet-i seniyye nâmına olarak hâsılâtdan tesviye edilir.", a.g.e. 
başşehbender ve bunun olmaması halinde fahri başşehbender maiyyetinde bulunurlar. Fahri şehbender vekilleri muvazzaf şehbender ve bunun olmaması halinde fahri şehbender maiyyetinde bulunurlar. ${ }^{66}$

Fahri şehbenderlerin memuriyetleri lağvedilir ise herhangi bir tazminat talep etmeye hakları olamaz. ${ }^{67}$ Fahri şehbenderler iflas eder veya kanunen mahkûm bulunurlarsa memuriyetlerinde istihdamları mümkün değildir. ${ }^{68}$ Fahri şehbenderler resmi sıfatı haiz olmak üzere memur veya vekil nasbedemezler. ${ }^{69}$ Bir haftadan fazla memuriyet mahallinden ayrılacak olan şehbenderler sırasıyla amirlerine ayrılık sürelerini ve kendilerine vekâlet edecek zâtı bildireceklerdir. ${ }^{70}$ Fahri şehbenderler (...) harcamaya yetkili oldukları masraflar ile şehbenderhane hasılatını içeren defteri her üç ayda bir Hariciye Nezareti'ne göndereceklerdir. ${ }^{71}$ Bu fasılda yazılı on bir bend ile düzenlenmeyen ve muvazzaf şehbenderlere dair olan sair hükümlerin tümü fahri şehbender hakkında da geçerlidir. ${ }^{72}$

\section{Çeşitli hükümler}

1881 Şehbenderler Dâhilî Nizamnamesi "ahkâm-1 umûmiye” başlı̆̆ı altında çeşitli hükümlere yer vererek sona ermektedir. Bu hükümlere göre, şehbender memurlarına verilmekte olan maaşlar beşinci bendde belirlenen maaş miktarından az ise, ileride belirlenecek miktara çıkarılmak üzere ödenmeye devam edecektir. ${ }^{73}$ Bir şehbender memuru her ne ad ve suretle olursa olsun, birden çok memuriyeti olsa da iki ve daha fazla yerden maaş alamayacaktır. ${ }^{74}$ Ve son olarak bir mahalde yeni bir şehbenderhane açılışıyla görevlendirilecek şehbendere verilecek maaş miktarı beşinci bendin hükümlerine bağlı olarak belirlenecektir. ${ }^{75}$

\section{Sonuç}

\footnotetext{
${ }^{66}$ Altmış ikinci bend: "Fahrî başşehbenderler mûkim oldukları memleketde bulunan sefâret-i seniyyeye merbût olub fahrî şehbenderler dahî silsile-i merâtîb kâidesine tevfîkân muvazzaf baş şehbender ve bunun fikdânı hâlinde fahrî başşehbender maiyyetinde bulunurlar. Fahrî şehbender vekîlleri muvazzaf şehbender ve bunun fikdânı takdirinde fahrî şehbender maiyyetinde bulunurlar.", a.g.e.

${ }^{67}$ Altmış üçüncü bend: "Fahrî şehbenderlerin me'mûriyetleri lağvedilir ise bir güna tazmînât taleb etmeğe hakları olamaz.”, a.g.e.

${ }^{68}$ Altmış dördüncü bend: "Fahrî şehbenderlerin izhâr-1 iflâs eder veya kânûnen mahkûm bulunur ise me'mûriyetlerinde istihdâmları câiz olunmaz.", a.g.e.

69 Altmış beşinci bend: "Fahrî şehbenderler sıfât-1 resmiyyeyi hâiz olmak üzere me'mûr veya vekîl nasbedemezler.", a.g.e.

${ }^{70}$ Altmış altıncı bend: "Bir haftadan ziyâde mahall-i me'mûriyetinden gaybûbet edecek olan şehbenderler sırası ile âmirlerine müddet-i gaybûbetlerini ihbâr edecekler ve kendilerine vekâlet eden zâtı dahî bildireceklerdir. Vekâlet eden zât fakat bir sûret-i gayr-i resmiyyede teb'a-i şâhâneyi himâye edebilir.”, a.g.e.

${ }^{71}$ Altmış yedinci bend: "Fahrî şehbenderler yirmi dokuzuncu bendde muharrer ta'limâta melfuf (4) işâreti ile murakkâm cedvel mûcibince me'zûn oldukları mesârif ile şehbenderhâne hâsılâtını mübeyyin Nezâret-i Hâriciye'ye her üç ayda bir defter irsâl edeceklerdir.”, a.g.e.

${ }^{72}$ Altmış sekizinci bend: "İşbu fasılda muharrer on bir bend ile ta'dîl olunmayan ve muvazzaf şehbenderlere dâir olan ahkâm-1 sâirenin kâffesi fahrî şehbender hakkında dahî câri olacakdır.", a.g.e.

${ }^{73}$ Altmış dokuzuncu bend: "Şehbender me'mûrlarına elyevm verilmekde olan maâşlar beşinci bendde ta'yîn olunan maâş mikdârından dûn ise ileride hadd-ı muayyenine iblâğ edilmek üzere hâlile ibkâ olunacakdır.”, a.g.e.

${ }^{74}$ Yetmişinci bend: "Bir şehbender me'mûru her ne nâm ve sûretle olur ise olsun velev ki müteaddid me'mûriyeti bulunsun iki ve daha ziyâde yerden maâş alamayacakdır.", a.g.e.

${ }^{75}$ Yetmiş birinci bend: "Bir mahalde müceddeden bir şehbenderhâne küşâdına me'mûr olacak şehbendere verilecek maâş mikdârı beşinci bendin ahkâmına tevfîkân ta'yîn olunacakdır.”, a.g.e.
} 
Altı yüzyılı aşan tarihinin ilk gününden son gününe kadar sürekli bir diplomasi mücadelesi vermiş̧ olan Osmanlı İmparatorluğu, tüm alanlarda olduğu gibi diplomasi alanında da bir değişim içinde varlığını devam ettirmiştir. Diplomatik ilişkilerini -tercümanlar, dönmeler gibi- diğer önemli unsurlara sahip olmakla birlikte fevkalade elçiler aracılığı ile yürüten imparatorluk, III. Selim döneminde oluşturulan ikamet elçilikleri ile diplomasi alanında yeni bir döneme girmiştir. Endüstri ve Fransız Devrimlerini gerçekleştirerek büyük bir değişim içine girmiş olan Batı ile doğrudan ve sürekli temas anlamına gelen ikamet elçiliklerinin kurulmasını, elçilik faaliyetlerinin gölgesinde yürütülmesine rağmen şehbenderlik hizmetlerinin başlatılması izlemiştir. Başlangıçta ticari rekabet kaygılarıyla oluşturulan şehbenderlik ağ1, 1821 yılına kadar 16 değişik şehre 25 şehbender ataması yapılarak genişletilmiştir. Yukarıda da bahsedildiği gibi 1821 Mora Ayaklanmaları sonrasında Sultan II. Mahmud elçilik faaliyetleri ile birlikte şehbenderlik faaliyetlerini de yasaklamış ve bu tarihten 1836'daki Hariciye Nezareti'nin kurulmasına kadar şehbenderlik faaliyetleri askıda kalmıştır.

Tanzimat ile birlikte imparatorluğun belli başlı alanlarında olduğu gibi dış işlerinde de değişim ve yenilik ivmesi yakalanmıştır. Bu dönem boyunca Osmanlı Hariciyesi’nin kazandığı yetkinlik, XIX. yüzyılın son çeyreğine girilirken bilhassa Mütercim Rüşdi Paşa, Midhat Paşa, Ahmed Cevdet Paşa, Safvet Paşa ve Ahmed Vefik Paşa gibi Tanzimat reformlarının önemini kavramış olan bürokratlar aracılığı ile II. Abdülhamid dönemine intikal etmiştir. Tanzimat'tan kalan bir geleneğin devamı olarak dış işlerinde oldukça önemli bir konumda bulunduğu anlaşılan şehbenderlik ağı, II. Abdülhamid döneminde de önemini koruyan bir müessese olmuştur. Genel olarak 1881 tarihli Şehbenderler Nizamnamesi'nden anlaşıldığına göre, şehbenderlerin imparatorluğu temsil vazifesi, yabanc1 ülkelerdeki Osmanlı tebaasının hak ve hukuklarını gözetme görevi ve yurtdışına özgü bazı idari işlere dair işlemlerin yürütülmesi sorumluluğu gibi görünürde ön plana çıkan misyonlarının yanı sıra, belki de bunların hepsinden önemli olan ve arka planda kalan bir misyonu daha vardır. Bu misyon da, bulundukları ülkedeki gelişmeleri dikkatle takip etmek, çeşitli unsurları -hafiye memuru ya da matbuat gibi açık kaynakları- kullanarak bilgi derlemek ve bu bilgiyi merkezi hükümetle paylaşmaktır. Dolayısıyla II. Abdülhamid dönemi boyunca dünyanın dört bir yanından telgraf başta olmak üzere dönemin iletişim araçları ile devlet merkezine ulaştırılan bilgi paylaşım sisteminin alt yapısının, bu tür nizamnamelerle hazırlandığını söylemek mümkündür.

\section{Kaynakça}

Akdemir, M. S. (2017). Arşiv Belgelerine Göre Osmanlı Dönemi Anadolu'da İran Şehbenderlikleri. Süleyman Demirel Üniversitesi İlahiyat Fakültesi Dergisi, S. 39, 40-67.

Akman, M. (2007). Tanzimat'tan Cumhuriyet'e Osmanlı Hukuk Mevzuatı I. Tertip Düstûr'un Tarihî Fihrist ve Dizini. Türk Hukuk Tarihi Araştırmaları, S. 3, 67-224.

Akpınar, M. (2001). Osmanlı Devleti’nde Şehbenderlik Müessesesi. Yüksek Lisans Tezi; Cumhuriyet Üniversitesi Sosyal Bilimler Enstitüsü, Sivas. 
Akpınar, M. (2014). Osmanlı İmparatorluğu'nda Hariciye Nezareti'nin Kuruluşu ve Dış Politikanın Kurumsallaşması. Tarih İncelemeleri Dergisi, XXIX/1, 59-85.

Akpınar, M. (2017). XIX. Yüzyılda Batıyla İlişkilerde Osmanlı Şehbenderlikleri. Cumhuriyet Üniversitesi Sosyal Bilimler Dergisi, C. 41, S. 2, 127-144.

Burçak, B. (2012). Osmanlı Sefaret Müessesesi ve 18. Yüzyıl Osmanlı Tarihi: Göçek’e Bir Alternatif. İçinde: Osmanlı Dünyasında Kimlik ve Kimlik Oluşumu, Baki Tezcan-Karl K. Barbir (Der.), Zeynep Nevin Yelçe (Çev.), İstanbul Bilgi Üniversitesi Yayınları, İstanbul, 175-180.

Erol, Y. Z. (2015). Şehbender Raporlarına Göre Osmanlı-Bulgaristan Ticari İlişkileri (19101914). Tarih Araştırmaları Dergisi, C. 34, S. 57, 221-248.

Karal, E. Z. (1940). Halet Efendi’nin Paris Büyükelçiliği (1802-1806). İstanbul Üniversitesi Edebiyat Fakültesi Tarih Semineri, XI, Kenan Basımevi, İstanbul.

Köprülü, F. (2006). Osmanlı İmparatorluğu'nun Kuruluşu. Akçağ Yayınları, 4. Baskı, Ankara.

Öztuna, Y. (1969). Devletler ve Hanedanlar, Türkiye (1074-1990). Kültür Bakanlığ1 Yayınları, Ankara.

Safi, M. (2011). Osmanlı Elçilerinin Wikileaks Raporları. Ural Yayıncılık, İstanbul.

“Saltanat-1 Seniyye Şehbenderlerine Dâir Nizâmnâme-i Dâhilîdir”, Düstûr, Tertip 1, Zeyl 2, İstanbul, 1299 (1882), 192-221.

Soysal, İ. (1990). Umûr-1 Hâriciye Nezâreti’nin Kurulması (1836). İçinde: Sultan II. Mahmud ve Reformları Semineri, 28-30 Haziran 1989 Bildirileri, İstanbul, 71-80.

Unat, F. R. (1968). Osmanlı Sefirleri ve Sefaretnameleri. Türk Tarih Kurumu Yayınları, Ankara.

Uzunçarşılı, İ. H. (1982). Osmanlı Tarihi. C. IV, I. Kısım, Türk Tarih Kurumu Yayınları, 3. Bask1, Ankara.

Uzunçarşı1ı, İ. H. (1983). Osmanlı Tarihi. C. IV, II. Kısım, Türk Tarih Kurumu Yayınları, 3. Bask1, Ankara.

Yalçınkaya, M. A. (2003). Kuruluştan Tanzimat'a Osmanlı Diplomasi Tarihi Literatürü. Türkiye Araştırmaları Literatür Dergisi, C. 1, S. 2, 423-489. 